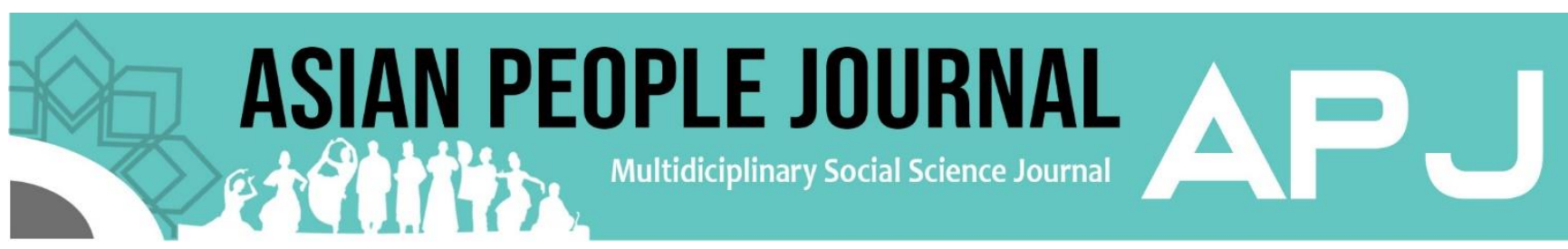

\title{
REALISME EKONOMI MASYARAKAT MALAYSIA DALAM KARYA INDIE
}

\section{(Malaysian Economic Realism in the Indie Masterpieces)}

\author{
Asyraff Jamin ${ }^{1 *}$, Mary Fatimah Subet ${ }^{1}$ \\ ${ }^{1}$ Fakulti Bahasa dan Komunikasi, Universiti Malaysia Sarawak (UNIMAS), 94300 Kota Samarahan, Sarawak, Malaysia \\ *Corresponding Author: asyraffjamin@gmail.com
}

Received: 29 May 2020 • Accepted: 1 November 2020 • Published: 30 April 2021

\begin{abstract}
Indie masterpieces are still not well received by the community now as it is still viewed as masterpieces that bring negative elements, taboos, aggressive attributes and unlike usual masterpieces such as prime literary masterpieces or serious masterpieces that have intellectual and aesthetic functions. This research will look into intellectual function of Indie masterpieces, whereby examining economy development thinking that is brought up in four Indie masterpieces, Aku Rindu 90's, Surat-Surat Untuk Kaherah, Kunang Pesisir Morten and Budak Kelas Belakang. This research is carried out qualitatively by using Georg Lukacs' realism criticism perspective to identify aesthetic values that are brought up based on the principles outlined by Georg Lukacs, such as art socialisation process as one of the effective medium to support economy, literature masterpieces as tools to fight economy domination, free literature criticism principles as well as literature masterpieces as transformational forces. Focused structural analysis was used to identify Indie writers' thinking towards developing community economy. Three objectives were set, which were to identify economy development thinking in Indie masterpieces, analyse Indie writers' masterpieces that are of same level with serious masterpieces, and lastly rectify community's perception towards Indie masterpieces which are developing fast in Malaysia. The research findings show that Indie masterpieces also bring intellectual function and serious thinking that could bring impact towards community development especially towards community economic stability. The findings of this research also clarify problems that often shadowing Indie masterpieces. It is clear that Indie masterpieces do not bring negative elements, taboos and aggressive attributes, instead they show intellectual functions and have aesthetic values.
\end{abstract}

Keywords: Indie masterpieces, Indie writers' thinking, economy development, Georg Lukacs' realism criticism 